\title{
Implementasi Energi Surya Sebagai Sumber Suplai Alat Pengering Pupuk Petani Portabel
}

\author{
Solly Aryza ${ }^{1}$, Hermansyah ${ }^{2}$, Andysyah Putera Utama Siahaan ${ }^{3}$, Suherman $^{4}$, \\ Zulkarnain Lubis ${ }^{5}$ \\ 1,5 Teknik Elektro Universitas Pembangunan Pancabudi Medan \\ 2,3,4 Program Studi Ilmu Komputer, Universitas Pembangunan Pancabudi Medan \\ E-mail : sollyaryzalubis@gmail.com, hermansyan@pancabudi.ac.id, \\ andysyahputerautama@gmail.com
}

\begin{abstract}
The energy from the sunlight is accommodated and then converted into electrical energy. The energy can then be used to run a variety of electronic devices ranging from turning on the lights, moving the motor, and many others. In this research make solar energy as an alternative energy to supply energy to portable fertilizer dryers in overcoming household electrical needs and also help farmers so that no longer need electricity sucked through PLN.
\end{abstract}

Keywords: Solar cell, Electricity requirement, electricity untapped PLN.

\begin{abstract}
Abstrak
Energi dari sinar matahari ditampung kemudian dikonversi menjadi energi listrik. Energi tersebut nantinya dapat digunakan untuk menjalankan berbagai macam alat elektronik mulai dari menyalakan lampu, menggerakkan motor, dan masih banyak lagi yang lainnya. Didalam penelitian menjadikan energi tenaga surya sebagai energi alternative untuk mensuplai energi ke mesin pengering pupuk portabel dalam mengatasi kebutuhan listrik rumah tangga dan juga membantu petani sehingga tidak memerlukan lagi listrik yang tersedot melalui PLN.
\end{abstract}

Kata Kunci : Solar Sel, Kebutuhan Listrik, Belum Terjamah Listrik PLN.

\section{PENDAHULUAN}

Indonesia bebagai negara tropis mempunyai potensi energi surya yang tinggi dengan radiasi harian rata-rata (insolasi) sebesar $4,5 \mathrm{kWh} / \mathrm{m} 2 /$ hari (Solarex, 1996). Potensi ini dapat dimanfa-atkan sebagai sumber energi alternatif yang murah dan tersedia sepanjang tahun. Disamping itu, kondisi geografis Indonesia yang terdiri dari ribuan pulau menyebabkan masih banyaknya daerah terpencil yang belum terjangkau listrik PLN. Oleh karena itu penerapan teknologi Pembangkit Listrik Tenaga Surya (PLTS) untuk memanfaat-kan potensi energi surya yang tersedia dilokasi-lokasi tersebut merupakan solusi yang tepat. Penerapan teknologi tenaga surya untuk kebutuhan listrik daerah terpencil dapat dilakukan dengan berbagai macam sistem pembangkit listrik tenaga surya, seperti pembangkit listrik hybrida yaitu gabungan antara sumber energi surya dengan sumber energi lainnya, yang paling umum adalah pengga-bungan energi surya dengan energi mesin diesel atau sumber energi mikro-hydro. Sistem tenaga surya lainnya adalah "Solar Home System" (SHS), yang terdiri dari panel modul surya, baterai, alat pengontrol dan lampu, sistem ini dipasang pada masing-masing rumah dengan modul fotovoltaik dipasang diatas atap rumah. Sistem ini biasanya mempunyai modul fotovoltaik dengan kapasitas daya $50 \mathrm{Wp}$ dimana pada radiasi matahari rata-rata harian 4,5 Kwh/m2 akan menghasilkan energi kurang lebih 125 s/d 130 watt-jam. Kendala penerapan SHS adalah 
IT Journal Research and Development

Vol.2, No.1, Agustus 2017

e-ISSN: 2528-4053

harga yang masih relatif mahal untuk masyara-kat terpencil dan miskin. Oleh karena itu perlu ada suatu panduan dalam meran-cang, menghitung dan memilih komponen yang diperlukan sehingga masyarakat tersebut mampu membayar dan dapat menikmati listrik seperti saudaranya yang sudah menikmati listrik, minimal untuk kebutuhan penerangan.
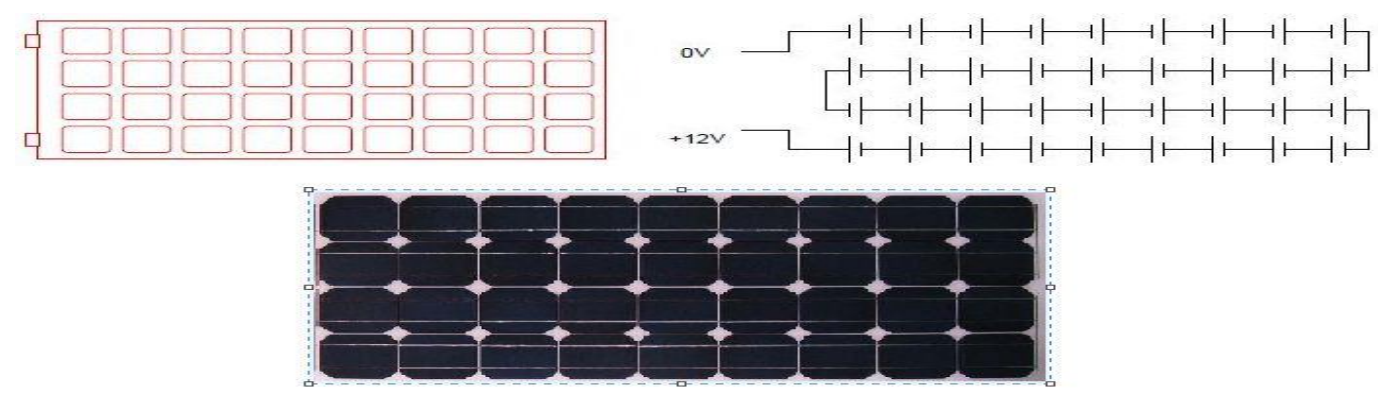

Gambar 1. Ilustrasi Dari Modul Surya

\section{METODOLOGI PENELITIAN}

Sel surya atau juga sering disebut fotovoltaik adalah divais yang mampu mengkonversi langsung cahaya matahari menjadi listrik. Sel surya bisa disebut sebagai pemeran utama untuk memaksimalkan potensi sangat besar energi cahaya matahari yang sampai kebumi, walaupun selain dipergunakan untuk menghasilkan listrik, energi dari matahari juga bisa dimaksimalkan energi panasnya melalui sistem solar thermal.

Sel surya dapat dianalogikan sebagai divais dengan dua terminal atau sambungan, dimana saat kondisi gelap atau tidak cukup cahaya berfungsi seperti dioda, dan saat disinari dengan cahaya matahari dapat menghasilkan tegangan. Ketika disinari, umumnya satu.

\subsection{Struktur Sel Surya}

Sesuai dengan perkembangan sains dan teknologi, jenis-jenis teknologi sel surya pun berkembang dengan berbagai inovasi. Ada yang disebut sel surya generasi satu, dua, tiga dan empat, dengan struktur atau bagian-bagian penyusun sel yang berbeda pula. Dalam tulisan ini akan dibahas struktur dan cara kerja dari sel surya yang umum berada dipasaran saat ini yaitu sel surya berbasis material silikon yang juga secara umum mencakup struktur dan cara kerja sel surya generasi pertama (sel surya silikon) dan kedua (thin film/lapisan tipis).

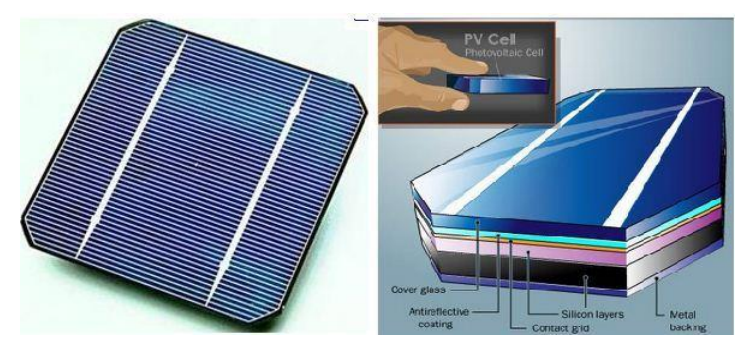

Gambar 2. Ilustrasi Sel Surya Dan Juga Bagian-Bagiannya

Substrat adalah material yang menopang seluruh komponen sel surya. Material substrat juga harus mempunyai konduktifitas listrik yang baik karena juga berfungsi 
sebagai kontak terminal positif sel surya, sehinga umumnya digunakan material metal atau logam seperti aluminium atau molybdenum. Untuk sel surya dye-sensitized (DSSC) dan sel surya organik, substrat juga berfungsi sebagai tempat masuknya cahaya sehingga material yang digunakan yaitu material yang konduktif tapi juga transparan sepertii ndium tin oxide (ITO) dan flourine doped tin oxide (FTO).

\subsection{Material Semikonduktor}

Material semikonduktor merupakan bagian inti dari sel surya yang biasanya mempunyai tebal sampai beberapa ratus mikrometer untuk sel surya generasi pertama (silikon), dan 1-3 mikrometer untuk sel surya lapisan tipis. Material semikonduktor inilah yang berfungsi menyerap cahaya dari sinar matahari. Untuk kasus gambar diatas, semikonduktor yang digunakan adalah material silikon, yang umum diaplikasikan di industri elektronik. Sedangkan untuk sel surya lapisan tipis, material semikonduktor yang umum digunakan dan telah masuk pasaran yaitu contohnya material $\mathrm{Cu}(\mathrm{In}, \mathrm{Ga})(\mathrm{S}, \mathrm{Se}) 2$ (CIGS), CdTe (kadmium telluride), dan amorphous silikon, disamping material-material semikonduktor potensial lain yang dalam sedang dalam penelitian intensif seperti $\mathrm{Cu} 2 \mathrm{ZnSn}(\mathrm{S}, \mathrm{Se}) 4$ (CZTS) dan Cu2O (copper oxide).

Bagian semikonduktor tersebut terdiri dari junction atau gabungan dari dua material semikonduktor yaitu semikonduktor tipe-p (material-material yang disebutkan diatas) dan tipe-n (silikon tipe-n, CdS,dll) yang membentuk p-n junction. P-n junction ini menjadi kunci dari prinsip kerja sel surya.

\subsection{Metode Sollar Home System}

Sistem PLTS yang cukup besar penerapannya di Indonesia adalah Sistem P juga sebagai sistem penerangan rumah secara individual (Solar Home System) dan disingkat SHS. Pemilihan sistem ini dalam penerapannya di pedesaan didasarkan atas kajian pertimbangan factor-faktor berikut :

- Pola pemukiman antara rumah di desa cukup menyebar

- Sulit untuk mendapatkan transportasi darat atau laut

- Belum memerlukan integrasi dengan pembangkit lain.

- Modular, dan mudah dikembangkan

- Kapasitas kecil sehingga mudah untuk di instalasi

- Harga terjangkau

- Radiasi matahari sebagai sumber energi mencukupi

- Tidak tergantung terhadap BBM

SHS adalah salah satu aplikasi sistem PLTS untuk pelistrikan desa sebagai sistem penerangan rumah secara individual atau desentralisasi dengan daya terpasang relatif kecil yaitu sekitar 48-55 Wp. Jumlah daya sebesar $50 \mathrm{Wp}$ per rumah tangga diharapkan dapat memenuhi kebutuhan penerangan, informasi (TV dan Radio) dan komunikasi (Radio komunikasi). Komponen-komponen utama SHS terdiri dari :

1. Modul fotovoltaic sebagai catudaya yang menghasilkan energi listrik dari masukan sejumlah energi matahari. 


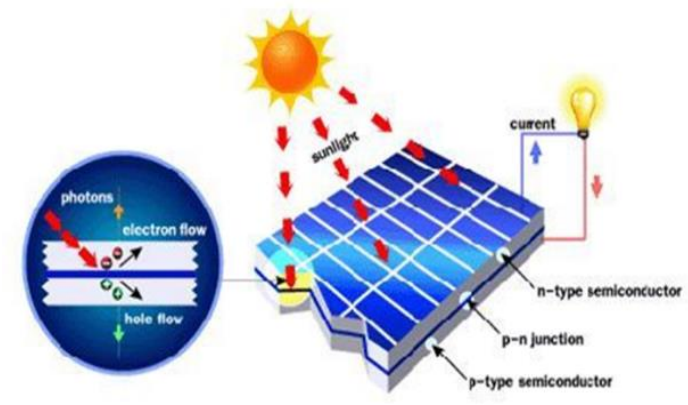

Gambar 3. Solar Home System

2. Baterai sebagai penyimpan dan pengkondisi energi.

3. Alat pengatur energi baterai (BCR) sebagai alat pengatur oomatis, penjaga kehandalan sistem.

4. Beban listrik seperti lampu TL (DC), saklar, radio, televisi dan lain-lain.

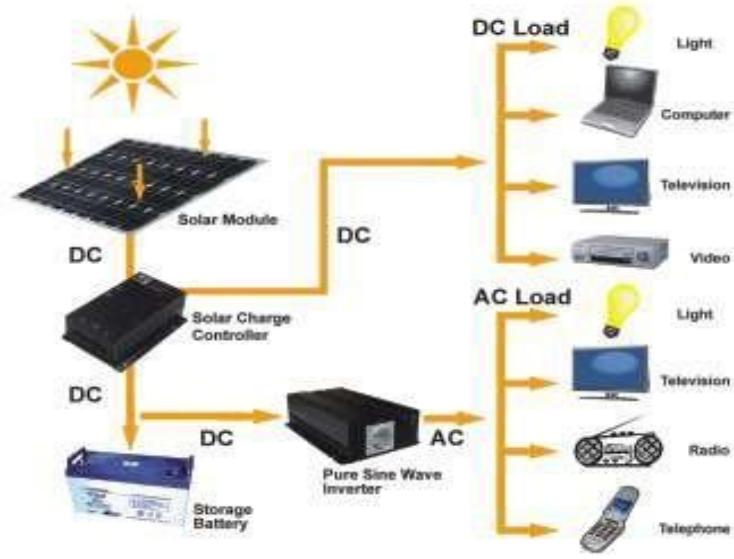

Gambar 4. Sistem Kerja Sel Surya

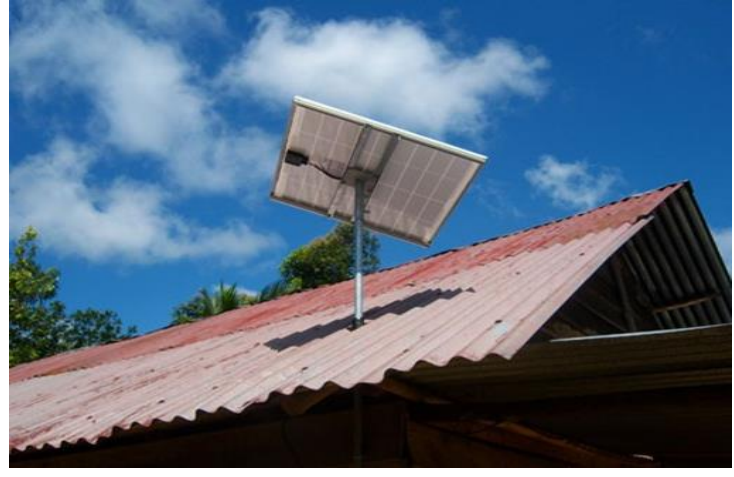

Gambar 5. Penampakan Tenaga Pengering Pupuk 


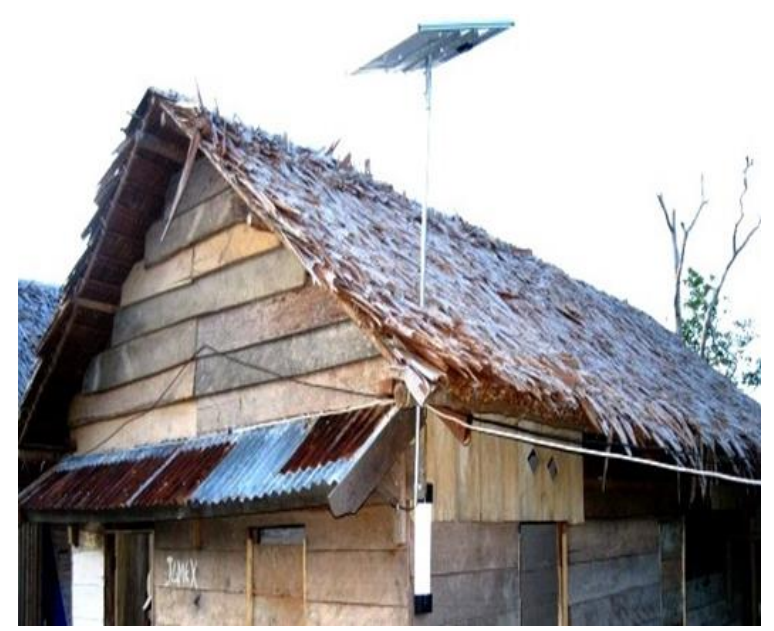

Gambar 6. Sistem Pengering Pupuk

\section{HASIL DAN PEMBAHASAN}

Perancangan dilakukan untuk menetukan ukuran sel Fotovoltaik dan Baterai untuk sistem energi matahari dengan kapasitas maksimum 1000 Watt. Langkah-langkah perancangan adalah sebagai berikut :

\subsection{Menentukan Arus Beban Total Dalam Ampere-Jam (Ah)}

Ampere-jam dari peralatan dihitung dalam DC ampere-jam/hari. Arus beban dapat ditentukan dengan membagi rating watt dari berbagai alat yang menjadi beban dengan tegangan operasi sistem PV nominal.

$I_{\text {tot }}$ beban $D C=$ Watt $/$ Vop $\times$ jam pakai sehari

$I_{\text {tot }}$ bebanAC $=($ Watt/Vopxjam pakai sehari $) / 0.8 \ldots \ldots$.

$I_{\text {tot beban }}=I_{\text {tot }}$ beban $D C+I_{\text {tot }}$ beban $A C$.

Dimana :

$I_{\text {tot }}$ beban $=$ Arus total beban dalam Ah

\subsection{Rugi-Rugi Dan Faktor Keamanan Sistem}

Untuk sistem PLTS dengan daya 1000 Watt ke bawah, factor $20 \%$ harus ditambahkan ke pembebanan sebagai pengganti rugi-rugi sistem dan untuk factor keamanan. Oleh karena itu ampere-jam beban yang ditentukan pada langkah 3.1 dikalikan dengan 1,20 sehingga :

Total beban + Rugi \& Safety Factor $=$ Itot beban $x 1,2 \ldots(4)$ 
IT Journal Research and Development

Vol.2, No.1, Agustus 2017

e-ISSN: 2528-4053

\subsection{Menentukan Jam Matahari Ekivalen (Equivalent Sun Hours, Esh) Terburuk}

Jam matahari ekivalen suatu tempat ditentukan berdasarkan peta insolasi matahari dunia yang dikeluarkan oleh Solarex (Solarex, 1996). Berdasarkan peta insolasi matahari dunia, diperoleh : ESH untuk Wilayah Sulawesi $=4,5$

\subsection{Menentukan Kebutuhan Arus Total Panel Surya}

Arus total panel surya yang dibutuhkan ditentukan dengan cara membagi 'Total beban + Rugi-rugi dan safety factor' dengan ESH.

Itot panel $=($ Itot beban $x 1,20) / E S H \ldots \ldots \ldots$

\subsection{Menentukan Kapasitas Baterai untuk Waktu Cadangan Yang Dianjurkan}

Umumnya sistem listrik matahari fotovoltaik dilengkapi dengan baterai penyimpan (Aki) untuk menyediakan energi pada beban ketika beroperasi pada malam hari atau pada waktu cahaya matahari kurang. Kapasitas waktu cadangan yang disarankan bervariasi berdasarkan garis lintang daerah tempat pemasangan panel surya diperlihatkan pada table 1. (Sumber : Solarex, 1996 : Discover The Newest World Power, Frederick Court, Maryland USA)

\section{Tabel 1. Hubungan Antara Lokasi Pemasangan Dan Waktu Cadangan Modul Photovolaik Buatan Solarex}

\begin{tabular}{|l|l|}
\hline Garis lintang lokasi pemasangan & Waktu cadangan \\
\hline $0^{\circ}-30^{\circ}$ (Utara atau Selatan) & $5-6$ hari \\
$30^{\circ}-50^{\circ}$ (Utara atau Selatan) & $10-12$ hari \\
$50^{\circ}-60^{\circ}$ (Utara atau Selatan) & 15 hari \\
\hline
\end{tabular}

Berdasarkan peta insolasi dunia (Solarex, 1996), letak wilayah Indonesia terletak pada 10o LS - 10o LU. Ini berarti bahwa waktu cadangan untuk seluruh wilayah Indonesia, termasuk Sulawesi Tengah, adalah sama yaitu $5-6$ hari.

Kapasitas Ampere-jam (Ah) Minimum dari baterai dihitung dengan persamaan :

Bateraicap $=($ Itot beban $\times 1,2) \times$ trec $\ldots .$.

\section{Dimana :}

Baterai cap $=$ kapasitas baterai (Ah)

Trec $=$ waktu cadangan 


\section{KESIMPULAN}

Berdasarkan uraian tersebut diatas, maka dapat ditarik kesimpulan bahwa di desa Pardamean Dusun Gunung Tua Kec.Pahae Jae Kab. Tapanuli Utara Prov.Sumatera Utara layak menggunakan energi tenaga surya sebagai sumber energi listrik untuk memenuhi kebutuhan listrik rumah tangga sebagai penerangan dimalam hari dan untuk keperluan lainya.

\section{SARAN}

Hasil dari penelitian ini masih belum sempurna, oleh karena itu ada beberapa saran yang mungkin dapat menjadi masukan bagi yang ingin mengembangkan penelitian di bidang ini. Saran untuk pengembangan penelitian yang lain adalah untuk coba menerapkan hasil penelitian ini di tempat - tempat yang masih belum masuk listrik ke daerah mereka.

\section{DAFTAR PUSTAKA}

[1] Alamanda, D., 1997, Prospek PLTS di Indonesia, ELEKTRO INDONESIA, Edisi ke Sepuluh.

[2] Prosedur Perancangan Sistem Pembangkit Listrik Tenaga Surya Untuk Perumahan /Solar Home System (Muhammad Bachtiar) Jurnal SMARTek, Vol. 4, No. 3, Agustus 2006: $176-182$

[3] Penerapan Teknologi PLTS Sebagai Solusi Untuk Membuka Keterisolasian Wilayah Pedalaman Dan Terpencil, BERITA BPPT, 2 Maret 2004

[4] Messenger, R., and Ventre, J., Photovoltaic Systems Engineering, CRC Press, Boca Raton USA.

[5] Mulyadi, Rahmad, 1995, Buku Panduan Pembangkit Listrik Tenaga Surya, Direktorat Teknologi Energi UPT-LSDE, BPPT.

[6] Patel, Mukund. R., 1999, Wind and Solar Power Systems, CRC Press, Boca Raton, Florida, USA.

[7] PT. LEN Industri, Buku Petunjuk Instalasi, Pengoperasian, \& Pemeliharaan Pembangkit Listrik Tenaga Surya (SHS 50 Watt peak).

[8] Solarex, 1993, Everything You Always wanted to know about Solar Power, Villawood Sydney, N.S.W. Australia.

[9] Solarex, 1996, Discover The Newest World Power, Frederick Court, Maryland USA.

[10] Wenas, W. W., 1996, Teknologi Sel Surya : Perkembangan Dewasa Ini dan yang Akan Datang, Majalah ELEKTRO INDONESIA, Edisi ke Empat

[11] Y. Arta, "Penerapan Metode Round Robin Pada Jaringan Multihoming Di Computer Cluster," Inf. Technol. J. Res. Dev., vol. 1, no. 2, pp. 26-35, 2017. 